\title{
Use of Chitosan Gel for the Purification of Protein
}

\author{
ZhenXing Tang ${ }^{1}$ and JunQing Qian ${ }^{2 *}$ \\ ${ }^{1}$ College of Chemical Engineering and Materials Science; Zhejiang University of Technology; Hangzhou, 310014; \\ Zhejiang China. ${ }^{2}$ College of Pharmaceutical Science; Zhejiang University of Technology; Hangzhou, 310014; \\ Zhejiang China
}

\begin{abstract}
The aim of this study was to optimize the preparation of chitosan gel and to use it for protein purification. The optimized preparation parameters were chitosan concentration $2.0 \%$, glutaraldehyde concentration $0.6 \%$, low cross-linking rate, $\mathrm{NaOH}$ concentration $1.6 \%$, amount of $\mathrm{NaBH}_{4} 0.4 \mathrm{~g}$. In order to use the chitosan gel, the elution conditions were optimized as follows. $\mathrm{NaCl}$ concentration $0.05 \mathrm{~mol} / \mathrm{L}$ in the tris- $\mathrm{HCl}$ ( $\mathrm{pH} \mathrm{9.05)} \mathrm{at} \mathrm{the} \mathrm{flow} \mathrm{rate} \mathrm{of}$ 2.03.0 mL/min. Particle size of chitosan gel was 120-140 $\mu \mathrm{m}$. Neutral protease could be separated into four ingredients through chitosan gel column. The yield of enzyme was more than $90 \%$. Albumin bovine serum could be separated into two ingredients through gel column and the total yield of albumin bovine serum was more than $70 \%$.
\end{abstract}

Key words: Chitosan, Gel, Preparation, Application

\section{INTRODUCTION}

Gels have been widely used for protein/enzyme separation in food and pharmaceutical industry (Braun et al., 1989 and Louis et al., 1979). At present, most of the gel carriers are sepharose such as sepharose CL-4B and sepharose CL-6B. However, sepharose has some drawbacks. Firstly, it is very expensive. Secondly, the preparation and regeneration of the gel are very difficult. Thus, it would be worth to make a new and low cost gel, which offers relative ease on the preparation and regeneration.

Chitin is an economical material and it represents part of marine resources (Muzzareli et al., 1997), which is widely distributed in fungal biomass, crustacean shells, etc (Robert et al., 1992).Since chitosan is soluble in acidic solutions, it is necessary to increase its chemical stability in acidic solutions for the sorption of several anions whose recovery is only effective at $\mathrm{pH}$ lower than
4-5 (Inoue et al., 1993; Guibal et al., 1999 and Larkin et al., 1999). The crosslinking treatment can be carried out using several chemical reagents such as glutaraldehyde (Guibal et al., 1999 and Larkin et al., 1999). Glutaraldehyde crosslinking treatment may affect the sorption efficiency, involving a decrease in the number of free amine groups and a decrease in the accessibility to internal sites. This restrictive effect may be decreased using chitosan whose structure has been physically modified. A gel bead formation procedure was proposed and investigated by several authors (Guibal et al., 1999 and Rorrer et al., 1993). This physical modification allows: (1) the polymer network to be expanded: the increase in the polymer network opening enhances the diffusion of large size molecules, and (2) the crystalline state of the polymer to be reduced. Piron et al (Piron et al., 1997) had shown that the dissolving of chitosan followed by a freeze-drying

\footnotetext{
* Author for correspondence
} 
of the resulting solution resulted in a strong decrease in the crystalline structure of the polymer, which in turn could be correlated to the improvement of sorption kinetics.

Chitosan has many excellent chemical properties similar to sepharose, such as chemical stability and compatibility with bioactive compounds. Hence, it could be used as gel carrier. Holme (Holme et al., 1988) studied chitosan grafted 1- $\beta$-D-furan, using this chitosan gel to separate protein, but the effect of separation was not good. Stenstad (Sentsad et al., 1989) used chitosan as the gel, but chitosan and the objective protein were difficult to be separated. Shi Y C et al prepared two kinds of chitosan affinity gel (Shi et al., 1996). The separation results were not effective too. The aim of this study was to optimize the preparation of chitosan gel and to use it for protein purification.

\section{MATERIALS AND METHODS}

\section{Materials}

Chitosan (deacetylation percentage 87\%) was provided by Yuhuan Ocean Biochemical Co. Lit (Zhejiang, China), Glutaraldehyde (25\%) was purchased from Wulian Chemical Factory (Shanghai, China); Albumin Bovine Serum was purchased from Huamei Bio-Chemical Factory
(Zhejiang, China); Neutral protease was a gift from Wuxi Enzymatic Preparation Factory (Jiangsu, China); All the other used reagents were analytical-grade quality and purchased from the local suppliers.

\section{Preparation of chitosan gel}

Chitosan $(1.0 \mathrm{~g})$ was dissolved in $2.0 \%$ acetic acid and filtered to remove insoluble materials. The dissolved chitosan was extruded into the $2.0 \%$ $\mathrm{NaOH}$ solution with a thin nozzle. Then chitosan was washed with distilled water repeatedly until it was neutral. Chitosan, distilled water and glutaraldehyde (25\%) were added to the flask for cross-linking. This procedure was carried out for 6 $\mathrm{h}$ at room temperature. Then $20 \mathrm{~mL} \mathrm{NaBH}_{4}(1.0 \%)$ was added and stirred for $24 \mathrm{~h}$ to block any residual aldehyde functional groups. This gel was filtered and thoroughly rinsed with distilled water until it was neutral. After the gel was sifted by the sieve, different sizes of chitosan gel were gotten.

\section{Orthogonal optimization of chitosan gel preparation parameters}

On the basis of single factor, five factors were selected to carry out orthogonal optimization experiments. The factors and the levels of the preparation of chitosan gel were listed in Table 1.

Table 1 - Factors and levels of the preparation of chitosan gel

\begin{tabular}{llccc}
\multicolumn{1}{c}{ Factors } & Level 1 & Level 2 & Level 3 & Level 4 \\
\hline Chitosan concentration / \% & 1.3 & 1.6 & 2.0 & 2.4 \\
Glutaraldehyde concentration / \% & 0.20 & 0.40 & 0.60 & 0.80 \\
The rate of cross-linking stirring / (r/min) & 50 & 150 & 200 & 600 \\
NaOH concentration / \% & 1.0 & 1.5 & 1.8 & 2.0 \\
The amount of reducing agent / g & 0.20 & 0.30 & 0.40 & 0.50 \\
\hline
\end{tabular}

\section{Stability of chitosan gel assay method}

Chitosan gel $(1.0 \mathrm{~g})$ was added to some acid solution. The mixture was shook for $1 \mathrm{~h}$ at room temperature, filtered with glass fibers. And then the aqueous sample was analyzed with UV/visible Spectrometer 751 (Shanghai, China) the wavelength was $540 \mathrm{~nm}$.

Adsorption ability of chitosan gel assay method Chitosan gel was packed into a column $(10 \mathrm{~mm} \times$ $300 \mathrm{~mm}$ ). The settled chitosan gel was equilibrated and eluted with distilled water. Albumin bovine serum was dissolved in the equilibrating buffer, whose protein concentration was $20 \mathrm{mg} / \mathrm{mL}$. Albumin bovine serum sample $(1 \mathrm{~mL})$ was loaded. The progress of elution was examined all the time by nucleic acid and protein detecting machine (Shanghai China), the eluate was collected by fractional collector machine (SBS-100 Shanghai China). The area of penetrating peak was calculated. 


\section{Determination of the elution system of chitosan gel}

Chitosan gel to be examined was packed into a column $(10 \mathrm{~mm} \times 300 \mathrm{~mm})$. The settled chitosan gel was equilibrated with distilled water. Neutral protease was dissolved in distilled water, whose concentration was $20 \mathrm{mg} / \mathrm{mL}$. $1 \mathrm{~mL}$ neutral protease sample was loaded. The elution system was $\mathrm{NaCl}(0-0.5 \mathrm{~mol} / \mathrm{L})$, tris- $\mathrm{HCl}(\mathrm{pH} 9.05)$, $\left(\mathrm{NH}_{4}\right)_{2} \mathrm{SO}_{4}(0-0.5 \mathrm{~mol} / \mathrm{L})$, phosphate buffer $(\mathrm{pH}$ 8.0), baritone- $\mathrm{HCl}$ ( $\mathrm{pH} 9.0)$, respectively. The progress of elution was examined all the time by nucleic acid and protein detecting machine (Shanghai China), the eluate was collected by fractional collector machine (Shanghai China).

\section{Optimization of elution conditions of chitosan gel}

Chitosan gel was packed and equilibrated (as above). Albumin bovine serum sample (20 $\mathrm{mg} / \mathrm{mL}, 1 \mathrm{~mL}$ ) was loaded. Under the optimized system (tris- $\mathrm{HCl} \quad \mathrm{pH}$ 9.05), different $\mathrm{Cl}^{-}$concentrations, different $\mathrm{pH}$ and different sizes of chitosan gel were selected to investigate their effect on the elution conditions respectively.

\section{Application of chitosan gel}

Chitosan gel was packed and equilibrated (as above). Albumin bovine serum sample (20 $\mathrm{mg} / \mathrm{mL}, 1 \mathrm{~mL})$ or neutral protease $(20 \mathrm{mg} / \mathrm{mL}, 1$ $\mathrm{mL}$ ) was loaded. Under the optimized elution conditions, albumin bovine serum and neutral protease were purified with chitosan gel respectively.

\section{Protein determination}

Protein determination was determined by the method of Folin-Lowry.

\section{Neutral protease assay}

Neutral protease activity was measured by the method of Jadwiga et al. (1998).

\section{RESULUTS AND DISCUSSION}

\section{Preparation of chitosan gel}

In order to separate out chitosan from the acid solution, the effect of alkali concentration on the amount of chitosan precipitated from the acid solution was examined.

Table 2 - Effect of alkali concentration on the mount of chitosan precipitated from the acid solution

\begin{tabular}{cc}
\hline The alkali mass concentration / \% & The mount of the chitosan precipitated from the acid solution / $\mathrm{g}$ \\
\hline 2.5 & 0.395 \\
2.0 & 0.390 \\
1.0 & 0.383 \\
0.5 & Little \\
$\mathrm{PH}=9.0$ & Minim \\
\hline
\end{tabular}

Table 3- Effect of glutaraldehyde concentration on the stability of chitosan gel

\begin{tabular}{cc}
\hline Glutaraldehyde concentration / \% & The stability in $\mathbf{p H ~ 1 . 5 ~ s o l u t i o n}$ \\
\hline 0.5 & Partial dissolution \\
0.6 & Dissolution \\
1.0 & Insoluble \\
1.5 & Insoluble \\
2.0 & Insoluble \\
\hline
\end{tabular}

Table 4 - Effect of glutaraldehyde concentration on the adsorption of chitosan gel

\begin{tabular}{cc}
\hline Glutaraldehyde concentration $/ \%$ & The penetrating peak area $/ \mathbf{~ c m}^{2}$ \\
\hline 0.6 & $0.6 \pm 0.10$ \\
1.0 & $6.3 \pm 0.30$ \\
1.5 & $12.0 \pm 0.10$ \\
2.0 & $24.4 \pm 0.20$ \\
2.5 & $46.1 \pm 0.50$ \\
\hline
\end{tabular}


Table 2 showed when $\mathrm{NaOH}$ concentration was over $1.0 \%$, the amount of the sedimentation of chitosan was high. But when $\mathrm{NaOH}$ concentration was below $1.0 \%$, the amount of the sedimentation of chitosan decreased. Hence, $1.0 \%$ alkali concentration was selected for subsequent experiments.

In order to investigate the effect of cross-linking solution on chitosan adsorption ability, the experiments were carried out about the stability and adsorption of chitosan gel at different crosslinking solution concentration. The results in Table 3 showed that when glutaraldehyde concentration was less than $0.6 \%$, chitosan gel was partially dissolved when solution $\mathrm{pH}$ was 1.5 ; when glutaraldehyde concentration was more than $0.6 \%$, chitosan gel was stable. With the increase of glutaraldehyde concentration, the degree of crosslinking was increased. The adsorption ability of chitosan gel was increasingly step-down. From this conclusion, we could know if the mount of glutaraldehyde concentration was more than the critical point, more amino groups in chitosan were reacted and less free amino groups were left. So the eluate peak area was large. Under the premise of stability of chitosan gel, the mount of crosslinking solution was as little as possible.

The effect of different degree of the deacetylation of chitosan on the adsorption ability was examined.

Table 5- Effect of the degree of deaectylation on the adsorption ability of chitosan gel

\begin{tabular}{cc}
\hline The degree of deacetylation $/ \%$ & The penetrating peak area $/ \mathbf{~ c m}^{2}$ \\
\hline 90.24 & 40.5 \\
87.52 & 77.5 \\
\hline
\end{tabular}

Table 6- Effect of chitosan concentration on the adsorption ability of chitosan gel

\begin{tabular}{cc}
\hline Chitosan concentration / \% & The penetrating peak area/ $\mathbf{~ c m}^{2}$ \\
\hline 1.0 & $42.3 \pm 0.50$ \\
1.5 & $12.0 \pm 0.10$ \\
2.0 & $0.60 \pm 0.10$ \\
2.5 & $3.70 \pm 0.20$ \\
3.0 & $21.3 \pm 0.40$ \\
\hline
\end{tabular}

The results in the Table 5 indicated higher the degree of the deacetylation of chitosan, the more was the amount of free amino groups in chitosan, resulting bigger adsorption ability of chitosan gel. Thus, the degree of the deacetylation of chitosan was $>90 \%$.

The experiment was carried out under different chitosan concentration. The results in Table 6 indicated that with the enhancement of chitosan concentration, the adsorption ability of chitosan gel was increased.

When chitosan concentration was $2.0 \%$, the adsorption ability of chitosan gel reached the highest; but when chitosan concentration was increased further, the adsorption ability of chitosan gel began to decrease. Hence, chitosan concentration $2.0 \%$ was selected for further studies. From the results in Tables 7 and.8, it could be seen that chitosan concentration was the most important factor, among all the factors affecting the preparation of chitosan gel. The second important factor was glutaraldehyde concentration. The optimization preparation parameter of chitosan gel was $\mathrm{A}_{3} \mathrm{~B}_{2} \mathrm{C}_{1} \mathrm{D}_{2} \mathrm{E}_{2}$., which contained (\%) chitosan 2.0, glutaraldehyde $0.6, \mathrm{NaOH} 1.6$, cross-linking rate $50 \mathrm{r} / \mathrm{min}$, and the amount of $\mathrm{NaBH}_{4}$ 0.4g.

From the results in Table 9, it could be seen that under the optimized situation the penetrating peak area was small and the adsorption ability of chitosan gel was big. Thus, the optimized preparation parameters were chitosan concentration $2.0 \%$, glutaraldehyde concentration $0.6 \%$, cross-linking rate $50 \mathrm{r} / \mathrm{min}$.

\section{Determination of the elution system of chitosan gel}

In order to get a good separation of protein and enzyme, the experiments were carried out under different elution systems.

The results in Fig. 1a showed that when the eluent peak reached the highest, it was no longer 
decreased. The eluent volume was high in the system of baritone- $\mathrm{HCl}$ ( $\mathrm{pH} \mathrm{9.0).} \mathrm{It} \mathrm{might} \mathrm{have}$ $\mathrm{UV}$ adsorption in baritone- $\mathrm{HCl}(\mathrm{pH}$ 9.0). The results in Fig. 1b-1 e showed that the peak shape was similar, but it had the phenomenon of trailing in the upper elution, which caused the enhancement of the eluent volume. The results in Fig. If showed that the peak shape was symmetrical and the mount of the eluent was small. Thus, tris- $\mathrm{HCl}$ system was selected the elution system.

Table 7-Experiments results of orthogonal test of chitosan gel's synthesis

\begin{tabular}{|c|c|c|c|c|c|c|}
\hline Number & $\begin{array}{c}\text { Chitosan } \\
\text { concentratio } \\
\text { n / \% }\end{array}$ & $\begin{array}{c}\text { Glutaraldehyd } \\
\text { e } \\
\text { concentration } \\
/ \%\end{array}$ & $\begin{array}{l}\text { The rate of } \\
\text { cross-linking } \\
\text { stirring / } \\
\text { (r/min) }\end{array}$ & $\begin{array}{c}\mathrm{NaOH} \\
\text { concentration } \\
/ \%\end{array}$ & $\begin{array}{c}\text { The } \\
\text { amount of } \\
\text { reducing } \\
\text { agent / g }\end{array}$ & $\begin{array}{c}\text { The } \\
\text { penetrating } \\
\text { peak area / } \\
\mathrm{cm}^{2}\end{array}$ \\
\hline 1 & 1 & 1 & 1 & 1 & 1 & $0.60 \pm 0.22$ \\
\hline 2 & 1 & 2 & 2 & 2 & 2 & $32.3 \pm 1.80$ \\
\hline 3 & 1 & 3 & 3 & 3 & 3 & $39.0 \pm 1.00$ \\
\hline 4 & 1 & 4 & 4 & 4 & 4 & $54.6 \pm 1.20$ \\
\hline 5 & 2 & 1 & 2 & 3 & 4 & $25.6 \pm 2.10$ \\
\hline 6 & 2 & 2 & 1 & 4 & 3 & $104 \pm 1.40$ \\
\hline 7 & 2 & 3 & 4 & 1 & 2 & $40.0 \pm 0.80$ \\
\hline 8 & 2 & 4 & 3 & 2 & 1 & $89.7 \pm 1.50$ \\
\hline 9 & 3 & 1 & 3 & 4 & 2 & $5.00 \pm 1.20$ \\
\hline 10 & 3 & 2 & 4 & 3 & 1 & $16.8 \pm 3.60$ \\
\hline 11 & 3 & 3 & 1 & 2 & 4 & $0.30 \pm 0.12$ \\
\hline 12 & 3 & 4 & 2 & 1 & 3 & $24.8 \pm 4.80$ \\
\hline 13 & 4 & 1 & 4 & 2 & 3 & $3.60 \pm 2.10$ \\
\hline 14 & 4 & 3 & 2 & 4 & 1 & $21.6 \pm 5.50$ \\
\hline 15 & 4 & 4 & 1 & 3 & 2 & $23.4 \pm 2.30$ \\
\hline 16 & 4 & 2 & 3 & 1 & 4 & $4.50 \pm 1.70$ \\
\hline $\mathrm{k}_{1}$ & 31.63 & 8.70 & 36.20 & 15.63 & 32.18 & - \\
\hline $\mathrm{k}_{2}$ & 62.83 & 37.40 & 19.95 & 37.60 & 25.18 & - \\
\hline $\mathrm{k}_{3}$ & 11.73 & 31.35 & 34.55 & 26.20 & 34.73 & - \\
\hline $\mathrm{k}_{4}$ & 13.28 & 42.00 & 28.75 & 44.30 & 27.38 & - \\
\hline $\mathrm{R}$ & 51.00 & 33.30 & 16.05 & 28.38 & 6.83 & - \\
\hline
\end{tabular}

The symbol $k_{1}, k_{2}, k_{3}$ and $k_{4}$ means the average at each of a factor.

Table 8-The repetitive experiment results under the optimized situation

\begin{tabular}{|c|c|c|c|c|c|}
\hline Source of variation & SS & $\begin{array}{l}\text { Degree of } \\
\text { freedom }\end{array}$ & $\begin{array}{l}\text { Means } \\
\text { square }\end{array}$ & $\begin{array}{c}\text { significance } \\
\mathbf{P}<0.05\end{array}$ & $\begin{array}{c}\text { significance } \\
\mathbf{P}<0.1\end{array}$ \\
\hline Chitosan concentration/ \% & 7314.387 & 3 & 18.656 & $*$ & $*$ \\
\hline Glutaraldehyde concentration / \% & 3353.742 & 3 & 8.554 & & $*$ \\
\hline $\begin{array}{l}\text { The rate of cross-linking stirring / } \\
\text { (r/min) }\end{array}$ & 392.062 & 3 & 1.000 & & \\
\hline $\mathrm{NaOH}$ concentration / \% & 1691.802 & 3 & 4.315 & & \\
\hline The amount of reducing agent / $g$ & 1130.862 & 3 & 2.884 & & \\
\hline Error & 392.06 & 3 & & & \\
\hline
\end{tabular}

Table 9-The repetitive experiment results under the optimized situation

\begin{tabular}{lcc}
\hline Number & The penetrating peak area $/ \mathbf{c m}^{2}$ \\
\hline & 1 & $0.41 \pm 0.01$ \\
& $0.44 \pm 0.02$ \\
\hline
\end{tabular}



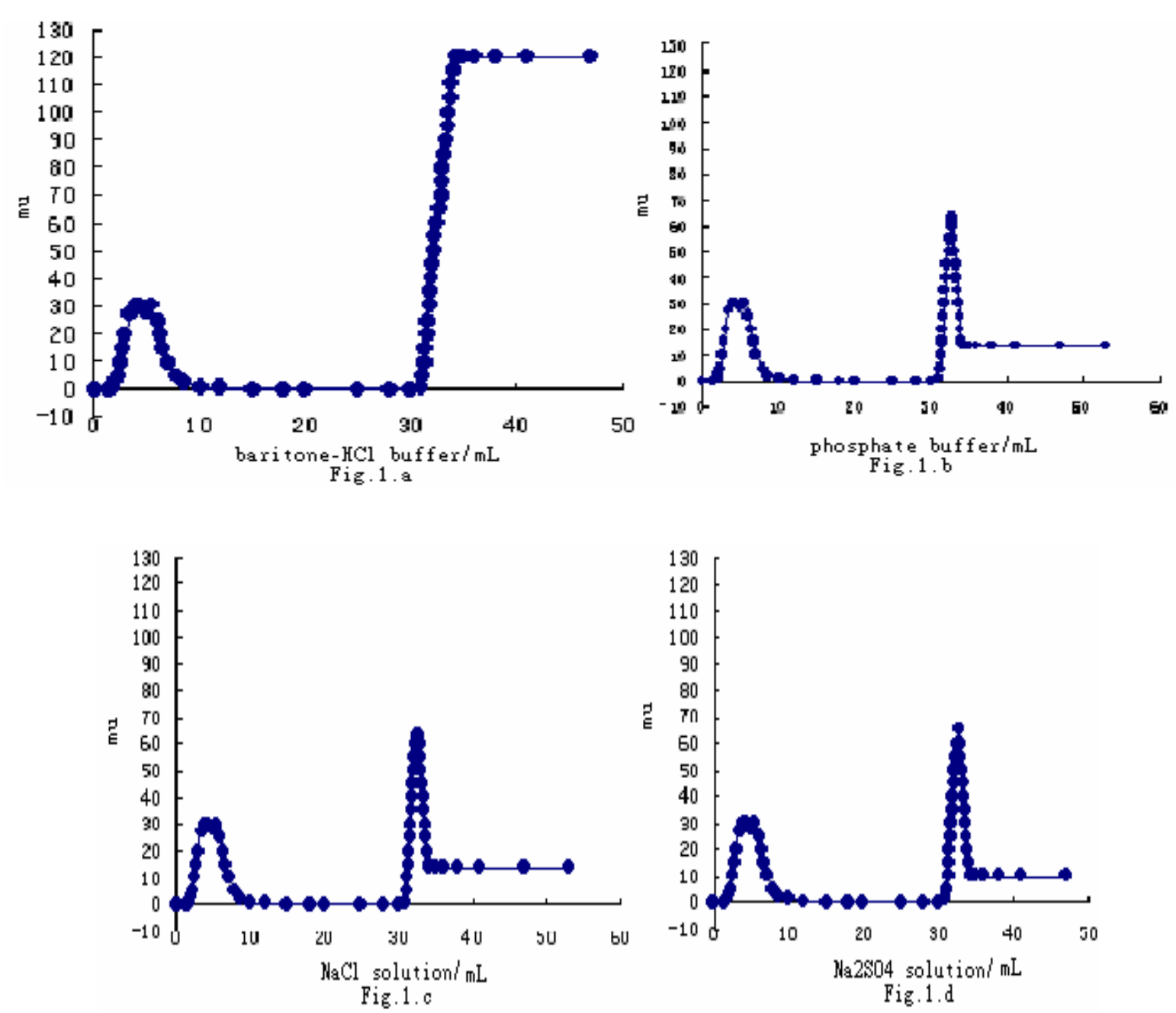

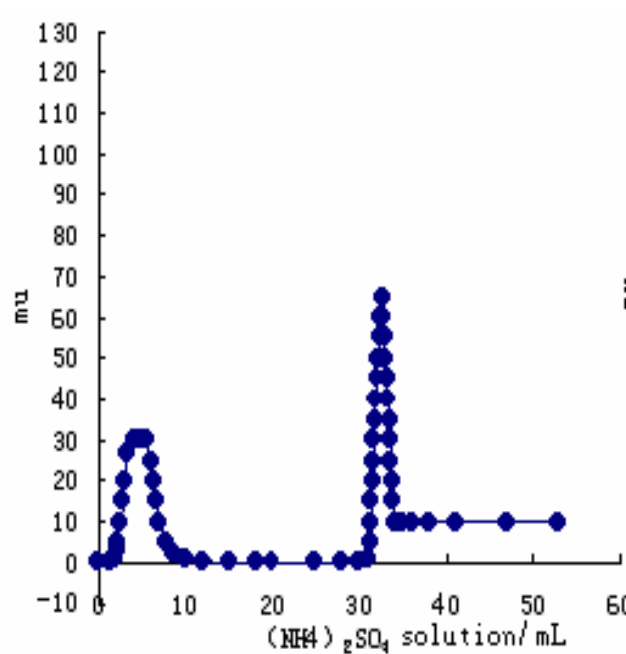

Fig.1.e

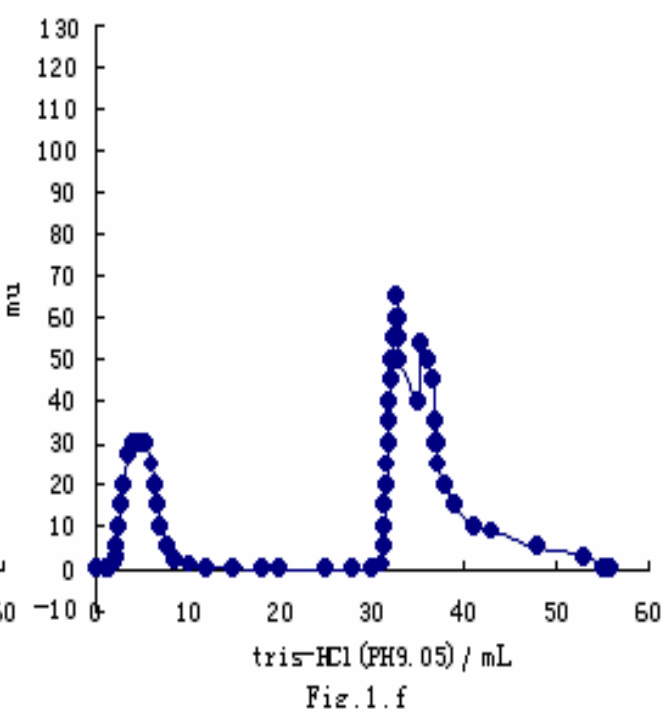

Figure 1- Elution curve under different elution systems The symbol mu means electric current. The second peak is enzyme peak. 

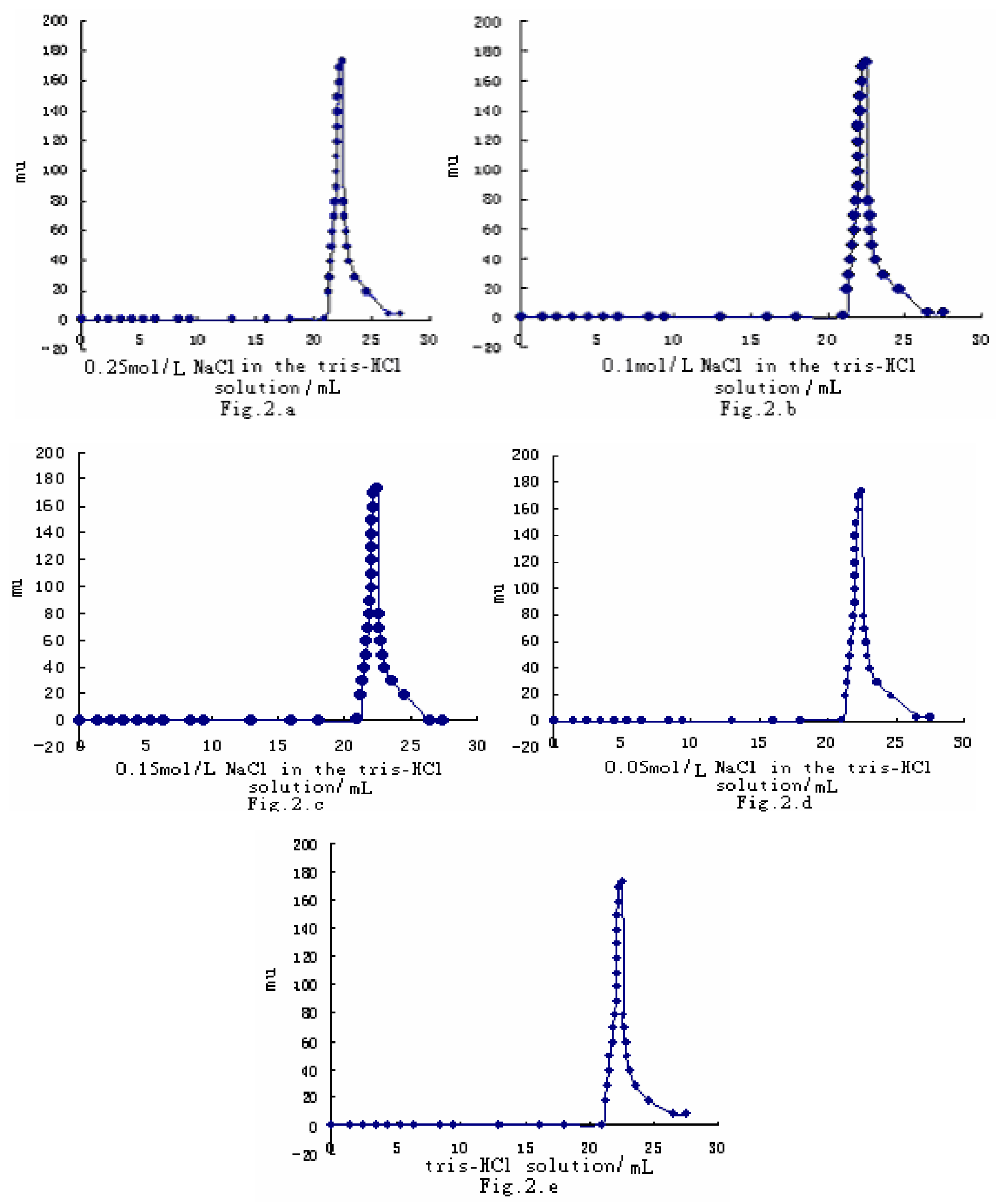

Figure 2 - Effect of ion strength on the elution condition of chitosan gel The symbol mu means electric current 

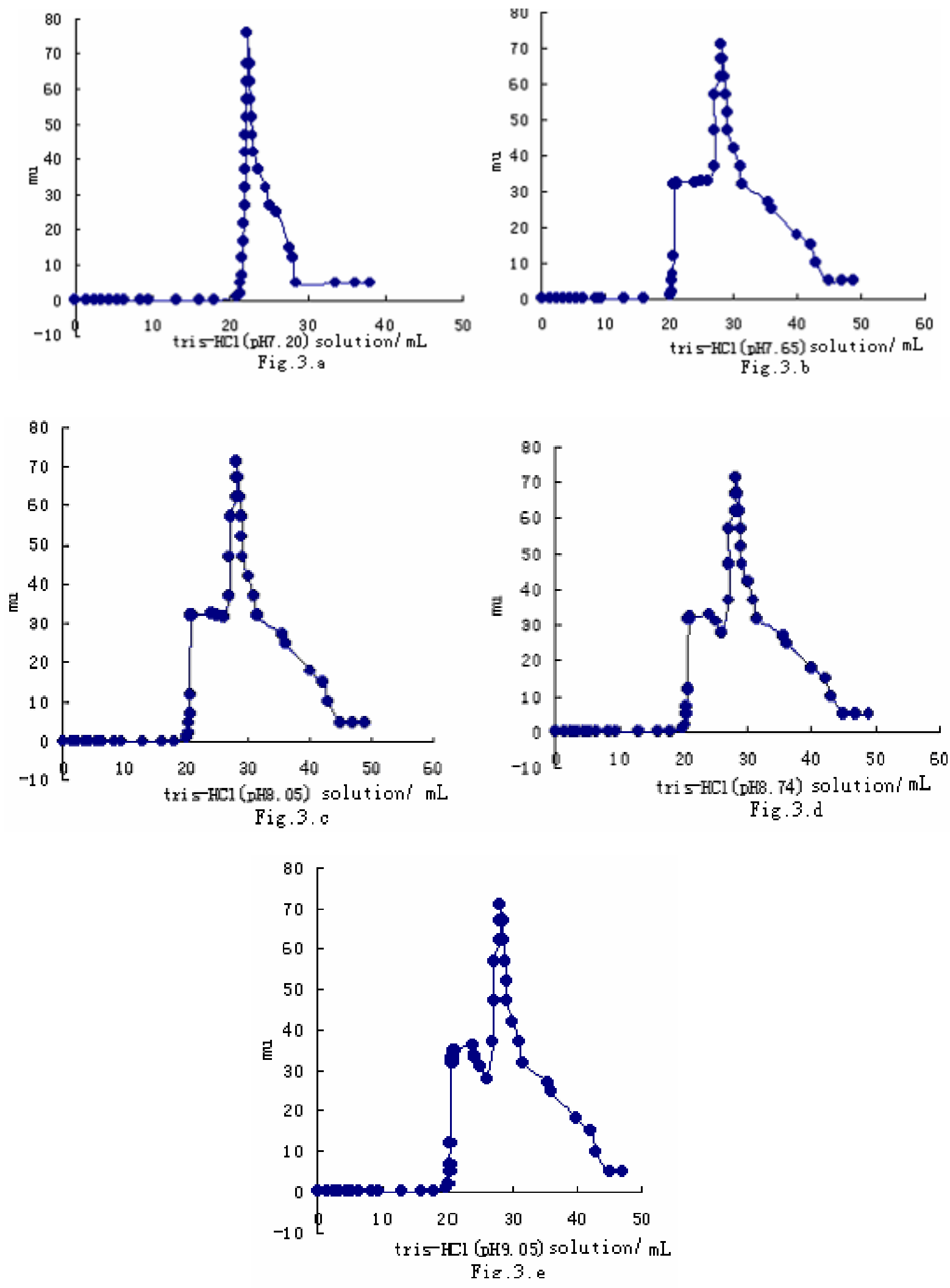

Figure 3 - Effect of $\mathrm{pH}$ on the eluent conditions The symbol mu means electric current 


\section{Optimization of elution conditions of chitosan gel}

When the ion strength was increased in the eluent solution, the competition to the absorbent site in the gel was enhanced too.

The results in Fig. 2 showed that with the enhancement of $\mathrm{NaCl}$ concentration, the elution peak had a trailing in separating albumin bovine serum. It might be that the hydrophobicity of the carrier was enhanced when $\mathrm{Cl}^{-}$concentration was increased. But when $\mathrm{NaCl}$ concentration $=0.05$ $\mathrm{mol} / \mathrm{L}$ in tris- $\mathrm{HCl}(\mathrm{pH} 9.05)$ solution, there was almost no trailing. It had a good peak shape. $\mathrm{NaCl}$ concentration $=0.05 \mathrm{~mol} / \mathrm{L}$ in tris $-\mathrm{HCl}(\mathrm{pH} 9.05)$ was selected as the eluent condition.



The exchange ability had a good relationship with solution $\mathrm{pH}$. In order to investigate the effect of $\mathrm{pH}$ on the elution condition, the experiments were carried out at different $\mathrm{pH}$ in tris- $\mathrm{HCl}$ solution. With the increase of solution $\mathrm{pH}$, the selectivity of albumin bovine serum was increased too. Albumin bovine serum could be divided into two peaks. With the increase of $\mathrm{pH}$, the ionization of chitosan was enhanced. The distance between $\mathrm{pI}$ and $\mathrm{pH}$ was bigger than before. Thus, tris- $\mathrm{HCl}(\mathrm{pH}$ 8.0-9.0) was selected.

If the surface of the carrier was different, the exchange ability was different. In order to investigate the effect of different sizes of chitosan gel on the eluent condition, the experiments were carried out using different sizes of chitosan gel.

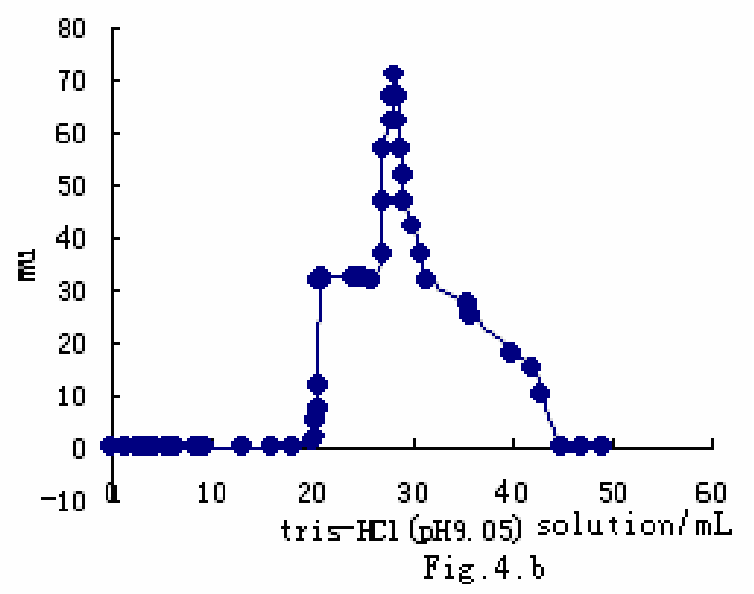

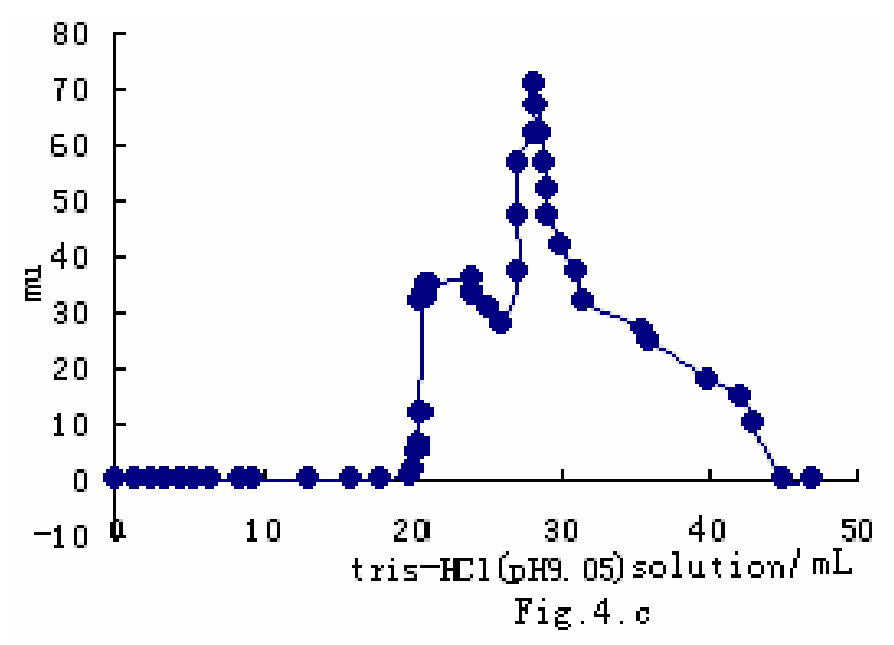

Figure 4- Effect of the different sizes of the gel on the eluent condition The symbol mu means electric current 
With the decrease of the size of chitosan gel, the separating power to albumin bovine serum was increased. But when the size of chitosan gel $(120-140 \mu \mathrm{m})$ was used, the eluent flow rate was too slow. From the angle of the application, chitosan gel $(<120 \mu \mathrm{m})$ was used.

\section{Application of chitosan gel}

Albumin bovine serum and neutral protease were purified with chitosan gel. The results were shown in Tables 9 and 10.

The results in Table 9 indicated that four ingredients peaks were obtained through chitosan gel. The activity peak mainly occurred in the peak 1 and activity yield was over $90 \%$. Results in Table 10 showed that two ingredients were gotten, and the protein recovery was over $70 \%$.

Table 9- The purification of neutral protease with chitosan gel

\begin{tabular}{cccccccc}
\hline Number & $\begin{array}{c}\text { Volume / } \\
\text { mL }\end{array}$ & $\begin{array}{c}\text { Total } \\
\text { protein / } \\
\text { mg }\end{array}$ & $\begin{array}{c}\text { Total } \\
\text { activity /U }\end{array}$ & $\begin{array}{c}\text { Specific } \\
\text { activity } \\
\text { /(U/mg) }\end{array}$ & $\begin{array}{c}\text { Purificatio } \\
\mathbf{n} \\
\text { factors }\end{array}$ & $\begin{array}{c}\text { Enzyme } \\
\text { activity /\% }\end{array}$ & $\begin{array}{c}\text { Protein } \\
\text { yield / \% }\end{array}$ \\
\hline Sample & 1.0 & 20.00 & 109.10 & 5.46 & - & - & - \\
Peak 1 & 12.0 & 2.74 & 29.4 & 10.7 & 1.97 & 27.0 & 13.7 \\
Peak 2 & 12.0 & 2.40 & 21.7 & 9.0 & 0.84 & 19.9 & 12.0 \\
Peak 3 & 11.0 & 2.51 & 27.0 & 11.5 & 1.28 & 24.7 & 12.6 \\
Peak 4 & 8.5 & 1.94 & 20.8 & 10.7 & 0.93 & 19.1 & 9.7 \\
Total & 42.5 & 9.59 & 98.9 & $\underline{-}$ & $\underline{ }$ & 90.7 & 48.0 \\
\hline
\end{tabular}

Table 10 - The purification of albumin bovine serum with chitosan gel

\begin{tabular}{cccc} 
Number & Volume $/ \mathbf{m L}$ & Total protein $/ \mathbf{m g}$ & Protein yield $/ \%$ \\
\hline Sample & 1.0 & 20 & $-\overline{2}$ \\
Peak1 & 21.5 & 5.6 & 28.2 \\
Peak2 & 25.0 & 8.4 & 42.0 \\
Total & 46.5 & 14.0 & 70.2 \\
\hline
\end{tabular}

\section{CONCLUSION}

Chitosan has many excellent chemical properties of sepharose, such as chemical stability and compatibility with bioactive compounds. Results of the study showed that chitosan could be used as gel carrier. Neutral protease could be separated into four ingredients through chitosan gel column with total activity above $90 \%$ under the optimized elution conditions. Albumin Bovine Serum could be separated into two ingredients through chitosan gel column, the total yield of which reached above $70 \%$ under the optimized elution conditions.

\section{REFERENCES}

J. Braun; P. Le Chanu and F. Le Goffic (1989), The immobilization of penicillin $\mathrm{G}$ acylase on chitosan Biotechnology and Bioengineering, 33: (2), 242-246.
L. J. Louis and W. Francios (1979), Immobilization of proteinases on Chitosan, Biotechnology Letters, 1: (3), 109-114

R.A.A. Muzzareli (1977), Chitin, Pergamon Press, Oxford, pp. 11

G. A.F. Robert (1992), Chitin Chemistry. MacMillan, London, pp. 22

K. Inoue; Y. Baba and K. Yoshizuka (1993), Adsorption of metal ions on chitosan and crosslinked copper ( $\square$-complexed chitosan. Bulletin of the Chemical Society of Japan, 66: (5), 2915-2921

E. Guibal; C. Milot and J.M. Tobin (1998), Metal-anion sorption by chitosan beads: equilibrium and kinetic studies. Industrial \& Engineering Chemistry Research, 37: (4), 1454-1463

E. Guibal; A. Larkin; T. Vincent and J.M. Tobin (1999), Chitosan sorbents for platinum sorption from dilute solutions. Industrial \& Engineering Chemistry Research, 38: (2), 401-412. 
G.L. Rorrer; T.Y. Hsien and J.D. Way (1993), Synthesis of porousmagnetic chitosan beads for removal of cadmium ions from waste water. Industrial \& Engineering Chemistry Research, 32: (9), 2170-2178

E. Piron; M. Accominotti and A. Domard (1997), Interaction between chitosan and uranyl ions role of physical and physicochemical parameters on the kinetics of sorption. Langmuir, 13: (6), 1653-1658

Holme K. R.; Hall L.D.; Armstrong C. R.; et al (1988), Synthesis and evaluation of chitosan-based affinity chromatography materials. Carbohydrate Research, 175: (2), 173-185.
Sentsad C. and Mattiasson B. (1989), Affinity-precipitation using chitosan a sligand carrier. Biotechnology and Bioengineering, 33: (2), 216-220.

Shi Y. C.; Jiang Y.M.; Sui D.X.; et al. (1996), Affinity chromatography of trypsin using chitosan sligand support. Journal of Chromatography A, 74: (1-2), 107-112

Jadwiga K. S. (1998), Purification and partial characterization of a neutral protease from a virulent strain of Bacillus cereus. The International Journal of Biochemistry \& Cell Biology, 30: (5), 579-595 
PÁGINA

EM

BRANCO 